\title{
USE OF THE NUTRIENT FILM TECHNIQUE AS A METHOD FOR ASSESSMENT OF PLANT RESPONSE TO SALT STRESS IN THE CEREALS
}

\author{
P. K. Martin, J. Humble', R. M. D. KoebneR \\ Cereals Research Department, Cambridge Laboratory, \\ JI Centre, Colney NR4 7UJ, England. \\ ${ }^{1}$ John Innes Institute, JI Centre, Colney NR4 7UH, England \\ (Received: April 24, 1994. Accepted: August 12, 199்)
}

\begin{abstract}
The nutrient film technique (NFT)/rockwool system was adapted for use as a method for assessing the response of wheat and barley to saline stress. Wheat plants grown by the NFT/rockwool system in $200 \mathrm{mmol} \mathrm{NaCl}$ were vegetatively more vigorous and were more fertile than when suspended over bowls containing the same saline nutrient solution. Signifcant intervarietal differential responses were observed in both wheat and barley for vegetative vigour under saline stress. By increasing the concentration of $\mathrm{NaCl}$ to $260 \mathrm{mM}$ and growing seedlings in miniaturized rockwool plugs, a screening system for salt tolerance in wheat, which allowed substantial plant numbers to be tested, was made possible. Seedlings which survived 4 weeks of this treatment could be successfully rescued into soil, where they developed normally.
\end{abstract}

KEY WORDS: Salt stress, hydroponics, nutrient film technique, cereals

\section{INTRODUCTION}

A growing proportion of arable land, pacticularly in the semi-arid sub-tropics, is being degraded by salinity, which has profound adverse effects on plant gcowth and development. The breeding of salt tolerant crop species is therefore an important goal, and much effort has been expended on the identification of genetic variation for this trait, particularly in the cereals. A fundamental requirement for such genetic screens is therefore the ability to impose a controlled salinity stress on the plant material. Field screening in saline affected soils is hampered by the inevitable non-uniformity of the environment, but artificial systems may not satisfactorily mimic soil conditions, and thus not be predictive of feld performance. In addition, for artifcial systems to be practical, they must be simple, inexpensive and reliable; it is clear that neither a germination test (Kingsbury and Epstein 1984) nor the bowl hydroponic system where plants are suspended above aerated solution (Gorham et al. 1985) fulfill these requirements; the former because the ability to germinate successfully is not predictive of the full plant response, and the latter both because it is impractical for large plant numbers, and also as it suffers from excessive non-genetic variation due possibly to the unintentional imposition of stresses other than salinity (Martin et al. 1993)

The nutrient film technique (NFT), in which plants are supported in a solid medium, and are fed by a moving film of nutrient solution, has been extensively used for commercial salad-crop and cut flower production (Sonneveld 1989, Blaabjerg 1984), and is thus readily adaptable to large-scale applications. Several support media are available: of these, rockwool is particularly convenient. Its physical and chemical properties have been investigated by Blaabjerg (1983). Rockwool-NFT has been used to study responses of lettuce (Lactuca sativa) to a number of nutritional factors (Thys et al. 1991). We describe its use as a system for studying the genetics of salt tolerance in cereals, and as the basis for a direct selection system for the high levels of tolerance present in certain of the wild relatives of bread wheat, Triticum aestivum (L.).

\section{MATERIALS AND METHODS}

\section{Hydroponics system}

The basic hydroponicum consists of a shallow plastic tray (internal dimensions $40 \times 60 \times 10 \mathrm{~cm}$ ), carrying the rockwool blocks (supplied by Grodania A/s, Hovedgaden 501, DK2640, Hedehusene, Denmark) set at $10^{\circ}$ from the horizontal, and a 20 litre catchment tank placed at the end of the tray. The nutrient solution is circulated from the tank to the head of the tray by a „Hozelock mini 100" submersible pump which delivers approximately $10 \mathrm{1} / \mathrm{min}$, and the solution is gravity-fed back into the tank via perforations in the floor of the bottom end of the tray (Fig. 1). The system was extended to a 4 tray -1 catchment tank apparatus (available in kit form), incorporating a simple automatic watering system, modified from that described by Clark (1916).

The nutrient solution consisted of either full strength culture solution (Hewitt 1966), or 1g/l Sangral 3:1:1 (obtained from Sinclair Horticulture and Leisure Ltd., Firth Road, Lincoln LN6 7AH, England) with the addition of $0.24 \mathrm{~g} / 1$ chelated $\mathrm{Fe}^{3+}$ (obtained from Atlas Interlates, Skelmersdale, Lancs WN8 9SX, England). The solution was changed 


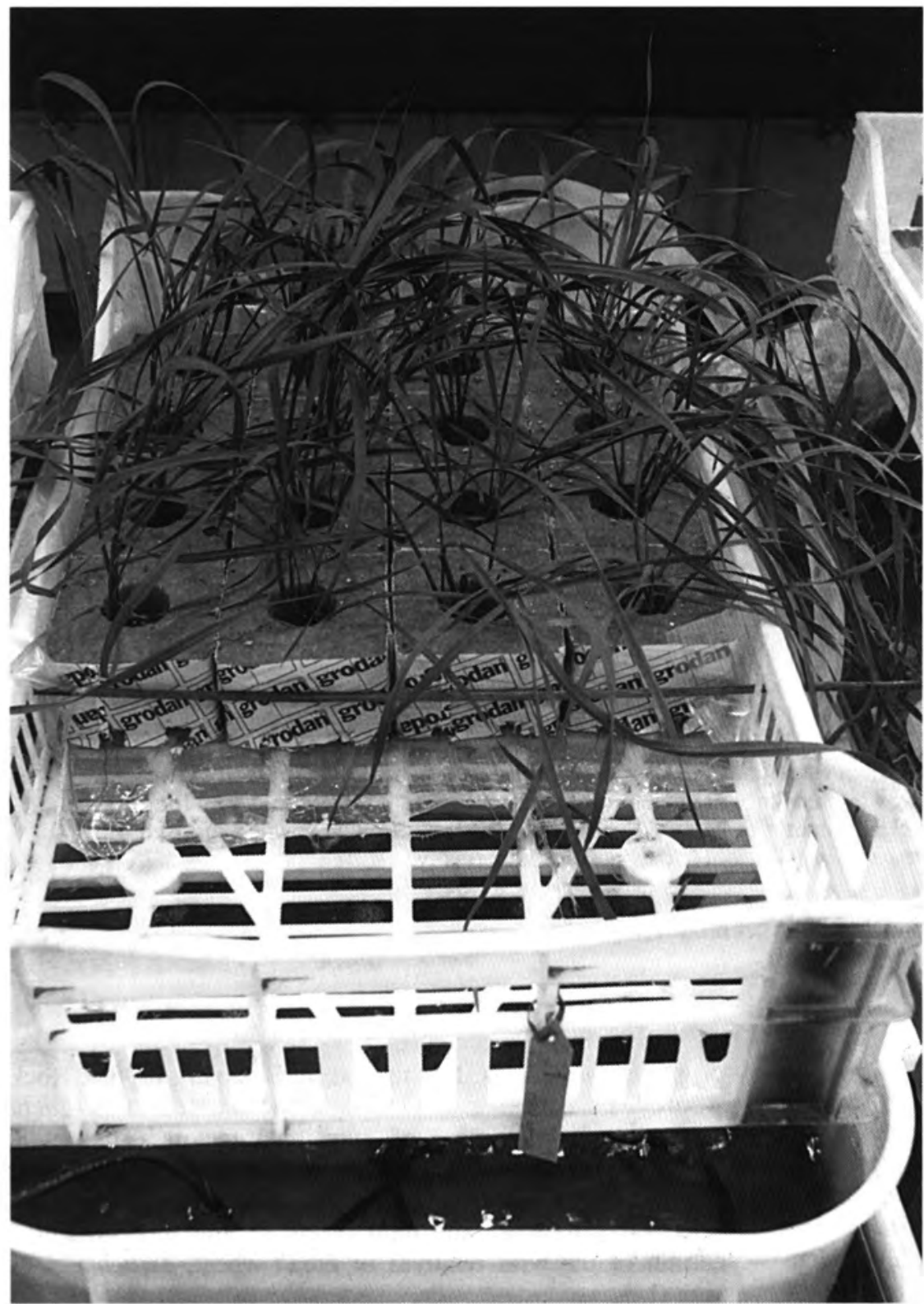

Fig. 1 Basic hydroponicum, showing plants growing in $10 \times 10 \times 7.5 \mathrm{~cm}$ rockwool bloks. weekly. In between changes, the residual saline nutrient held in the blocks was removed by flushing the system four times for about 30 minutes each time with tap water. The volume of solution was maintained daily by the addition of tap water to compensate for evaporative and transpirational loss. Salt treatment was imposed by the single addition to the tank of the appropriate weight of solid $\mathrm{NaCl} / \mathrm{CaCl}_{2}$; step-wise addition of salt was not found to improve plant response. Some agitation of the tank solution was necessary to dissolve the salt fully. Chitted seed was placed in depressions in the rockwool block, and covered with vermiculite. Where appropriate, the salt was added when the first seedling leaf of the majority of the plants was fully expanded. The experiments were conducted in a lit (nominal 18 hours daylength) and heated (mean $20^{\circ} \mathrm{C}$ ) glasshouse over winter.

\section{Experiment 1}

The bread wheat intervarietal single chromosome substitution line Chinese Spring(Ciano 2D), in which chromosome 2D from cv. Ciano 67 replaces that of cv. Chinese Spring
(CS) in a reconstituted CS background (Law 1984) was grown as one plant per $10 \times 10 \times 7.5 \mathrm{~cm}$ rockwool block, and subjected to either $200 \mathrm{mM} \mathrm{NaCl} / 10 \mathrm{mM} \mathrm{CaCl}_{2}$ in full strength culture solution, or $0 \mathrm{mM} \mathrm{NaCl}$ as control. Each genotype was represented by 10 individuals per treatment, randomized across the tray. Plants were supported, where necessary, by suspending layers of clematis netting above the tray, and were grown to maturity. Shoot dry weights. ability to set seed, height of the main tiller, tiller number and days to ear emergence of the main tiller were recorded.

\section{Experiment 2}

To survey intraspecific variation in salt response, the enlarged hydroponicum was employed, using the $10 \times 10 \times 7.5 \mathrm{~cm}$ blocks. Each block was planted with two chitted seeds of a single genotype, and each genotype block was represented twice on each tray. Each tray contained the full range of genotypes, arranged randomly. The genotypes were: bread wheat cvs. CS, Glennson, two salt tolerant Kharchia selections Kharchia 1 (PI322279) and Kharchia 2 (PI322280) obtained 
from the US National Small Grains Collection, and the salt tolerant disomic addition of Thinopyrum bessarabicum chromosome $5 \mathrm{E}^{\mathrm{b}}$ to $\mathrm{CS}$ (Forster et al. 1988) $\left(5 \mathrm{E}^{\mathrm{b}}\right)$; and barley (Hordeum vulgare) cvs. Blenheim and Digger. A salt concentration of $200 \mathrm{mM} \mathrm{NaCl} / 10 \mathrm{mM} \mathrm{CaCl}_{2}$ was imposed. Plants were grown to maturity, and shoot dry weight, height of main tiller, days to ear emergence and \% survival (where survival was defined as the ability to reach ear emergence) were recorded.

\section{Experiment 3}

This experiment was designed to test the system as a selective tool for high levels of salt tolerance. Chitted seed were sown into $2.5 \times 2.5 \times 4 \mathrm{~cm}$ rockwool plugs, which were supported by the manufacturer's tray. This allowed 180 seedlings to be screened in a single hydroponicum. The seedlings were fed with Sangral solution containing $260 \mathrm{mM} \mathrm{NaCl} / 13 \mathrm{mM}$ $\mathrm{CaCl}_{2}$. Surviving seedlings were rescued after four weeks in salt from one hydroponicum, and after six weeks in the remaining two units. For rescue, the plugs were rinsed in water and potted directly into John Innes No. 2 soil. The plant material consisted of derivatives from the cross between the highly salt tolerant amphiploid CS (Ciano 2D) x Th. bessarabicum described by Martin et al. (1993), and CS (Ciano 2D). Control genotypes were the wheat and amphiploid parents of this material.

The data (arcsin transformed where recorded as percentages) from Experiments 1 and 2 were statistically analysed using Genstat 5.

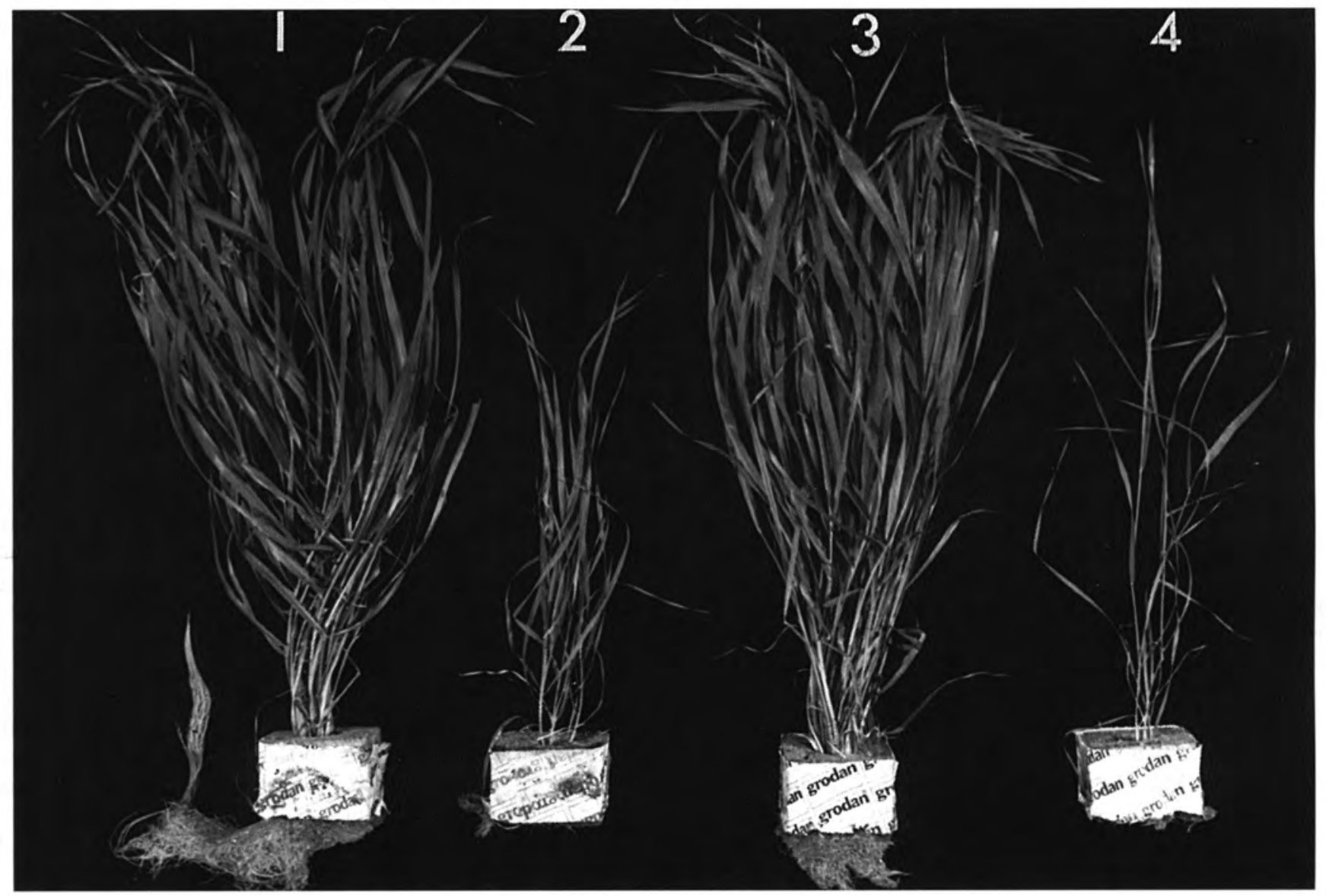

Fig. 2 NFT-grown plants of CS $(1,2)$ and CS (Ciano 2D) $(3,4)$, grown in $0 \mathrm{mM} \mathrm{Na} \mathrm{Cl}(1,3)$ and $200 \mathrm{mM} \mathrm{NaCl}(2,4)$.

\section{RESULTS}

\section{Experiment 1}

The dry matter yield of CS (Ciano 2D) in the control treatment was more than double that achieved with the same genotype using the bowl hydroponic system (Martin et al. 1993), largely as a result of much higher tillering (unpublished data). As anticipated, the salt treatment significantly reduced plant performance for all the characters measured (Fig. 2). Dry matter yield and tiller number in the salt treatment were approximately three times those recorded for the same genotypes, grown at a lower salt concentration (175
$\mathrm{mM} \mathrm{NaCl} / 8.75 \mathrm{mM} \mathrm{CaCl}_{2}$ ) with the bowl hydroponicum (Martin et al. 1993).

\section{Experiment 2}

The analysis of variance for this experiment is summarized in Table 2. There was no significant block effect for any of the characters measured, indicating that the system provides a uniform environment within a tray. The presence of significant tray effects for a number of characters is thought to have resulted from uneven supplemental lighting. There were strong genotypic effects for all characters measured. 
TABLE 1 The single chromosome intervarietal substitution line CS (Ciano 2D) grown in the hydroponic NFT/rokwool system. The control treatment consisted of an optimized culture solution, and salt treatment contained, in addition, $200 \mathrm{mM} \mathrm{NaCl} / 10 \mathrm{mM} \mathrm{CaCl} 2(\mathrm{Ex}-$ periment 1). DWT: shoot dry weight in $\mathrm{g}$ at maturity, HT: above ground height in $\mathrm{cm}$ at maturity, TNO: tiller number, TTEE: days to ear emergence.

S.E. - Standard error. Figures with the same letter do not differ significantly, $\mathrm{p}<0.01$.

\begin{tabular}{lccr}
\hline & CONTROL & SALT & S.E. \\
\hline DWT & $35.6 \mathrm{a}$ & $5.2 \mathrm{~b}$ & 8.08 \\
HT & $122.0 \mathrm{a}$ & $73.0 \mathrm{~b}$ & 10.90 \\
TNO & $22.86 \mathrm{a}$ & $5.57 \mathrm{~b}$ & 1.44 \\
TTEE & $72.71 \mathrm{a}$ & $53.57 \mathrm{~b}$ & 3.55 \\
\hline
\end{tabular}

TABLE 2 Summary of the analysis of variance of Experiment 2.

\begin{tabular}{lcccc}
\hline Block & Genotype & Tray & $\begin{array}{c}\text { G.type* } \\
\text { Tray }\end{array}$ \\
\hline DWT & NS & $* *$ & $* *$ & NS \\
HT & NS & $* *$ & NS & NS \\
TNO & NS & $* *$ & $* *$ & NS \\
TTEE & NS & $* *$ & $* *$ & $* *$ \\
$\%$ S & NS & $* *$ & NS & NS \\
$\%$ SS & NS & $* *$ & NS & NS
\end{tabular}

$\%$ S: of plants surviving to ear emergence; $\%$ SS: \% of plants setting at least one selfed seed.

Other abbreviations as in Table 1. ***=significant at $1 \%$ level of probabilility, NS=non-significant.

The genotypic means are presented in Table 3, and they confirm the existence of a considerable degree of genetic variation both in wheat and in barley (Table 2). Of the wheats, CS produces the most dry matter, the tallest plants, the highest tiller number. and one of the highest survival rates. In contrast, Glennson, which is known to be a salt susceptible cultivar (Mahmood and Quarrie 1993), has poor survival, and those plants which do survive have low vigour (Fig. 3). The disomic addition line $5 \mathrm{E}^{\mathrm{b}}$, reported to confer both superior vegetative vigour and ability to set seed at
$200 \mathrm{mM} \mathrm{NaCl}$, as compared to CS (Forster et al. 1988), survives well, but does not produce as much dry matter or as many tillers as CS itself. The Kharchia lines, which have originated from field selection for salinity tolerance, survive well, but produce low amounts of dry matter, partly because of their extreme early flowering. The barley comparison produced significant differentiation between cvs. Blenheim and Digger, with respect to their ability to flower at this level of salt stress, but even Blenheim, the more tolerant of the two, was unable to produce substantial dry matter (Fig. 3B).

\section{Experiment 3}

After four weeks at $260 \mathrm{mM} \mathrm{NaCl} / 13 \mathrm{mM} \mathrm{CaCl}_{2}, 10$ backcross derivative seedlings remained green, as did all the amphiploid controls. The remaining plants were desiccated. Six plants survived rescue and have produced progeny for further testing. Of the 357 backcross derivative seedlings subjected to six weeks of stress, 19 remained green, but only one of these survived rescue (Fig. 4); the three amphiploid controls all survived both treatment and rescue and gave rise to vigorous fertile plants.

\section{DISCUSSION}

Using a number of quantitative plant traits such as tiller number, dry matter accumulation and ability to survive to ear emergence, the NFT system clearly provides better growth conditions than does the bowl system, both for control and saline treatments. Presumably this is a result of a less stressful root environment, both in terms of physical support of the root system and in terms of the maintenance of a well-aerated nutrient supply. Hence there are likely to be lower levels of unintended stress, and this allows a fuller expression of the genetic potential of plants subjected to salt stress alone, and thus the more efficient discrimination of genetic differences. Despite this improvement, there is still a substantial within genotype element of variation, which obscures the picture, and current experiments are aimed at reducing this further, by eliminating seed size and seed ionic content as variables. Nevertheless, it has now been possible to uncover reproducible inter-varietal differences in salt tolerance both between bread wheat and between barley varieties, and this will now allow an analysis of the genetical basis of this salt tolerance, using a quantitative trait locus (QTL) approach applied to double haploid populations.

TABLE 3 Comparison between the bread wheats Chinese Spring (CS) and Glennson (GL), the salt tolerant selections Kharchias 1 (K1) and 2 (K2) and the disomic addition line of Th. bessarabicum chromosome $5 \mathrm{E}^{\mathrm{b}}$ in a CS background (5E $\mathrm{E}^{\mathrm{b}}$ ); and the barleys Digger (DI) and Blenheim (BL). The plants were grown in the enlarged hydroponicum and irrigated with optimized culture solution $\mathrm{plus} 200 \mathrm{mM} \mathrm{Na} \mathrm{Cl} / 10 \mathrm{mM} \mathrm{CaCl} 2(\mathrm{Ex}-$ periment 2).

\begin{tabular}{l|c|c|c|c|c|c|c|c}
\hline & $\mathrm{CS}$ & $\mathrm{GL}$ & $\mathrm{K} 1$ & $\mathrm{~K} 2$ & $5 \mathrm{E}^{\mathrm{b}}$ & $\mathrm{BL}$ & DI & S.E. \\
\hline DWT & $2.8 \mathrm{~d}$ & $0.4 \mathrm{ab}$ & $1.0 \mathrm{~b}$ & $0.9 \mathrm{~b}$ & $1.5 \mathrm{c}$ & $0.6 \mathrm{ab}$ & $0.3 \mathrm{a}$ & 0.5 \\
HT & $51.4 \mathrm{~d}$ & $17.9 \mathrm{a}$ & $44.6 \mathrm{~d}$ & $38.9 \mathrm{~cd}$ & $35.1 \mathrm{c}$ & $28.5 \mathrm{~b}$ & $8.9 \mathrm{a}$ & 9.2 \\
TNO & $3.4 \mathrm{c}$ & $1.1 \mathrm{a}$ & $1.1 \mathrm{a}$ & $1.4 \mathrm{ab}$ & $1.9 \mathrm{~b}$ & $1.1 \mathrm{a}$ & $1.5 \mathrm{ab}$ & 0.5 \\
TTEE & $62.2 \mathrm{e}$ & $49.0 \mathrm{c}$ & $44.5 \mathrm{~b}$ & $42.9 \mathrm{~b}$ & $55.1 \mathrm{~d}$ & $67.2 \mathrm{f}$ & - & 2.9 \\
$\%$ S & 81.0 & 25.0 & 94.0 & 69.0 & 88.0 & 63.0 & 0 & - \\
$\%$ SS & 81.0 & 13.0 & 75.0 & 50.0 & 88.0 & 0 & 0 & - \\
\hline
\end{tabular}

Abbreviations as in Tables 1 and 2. 

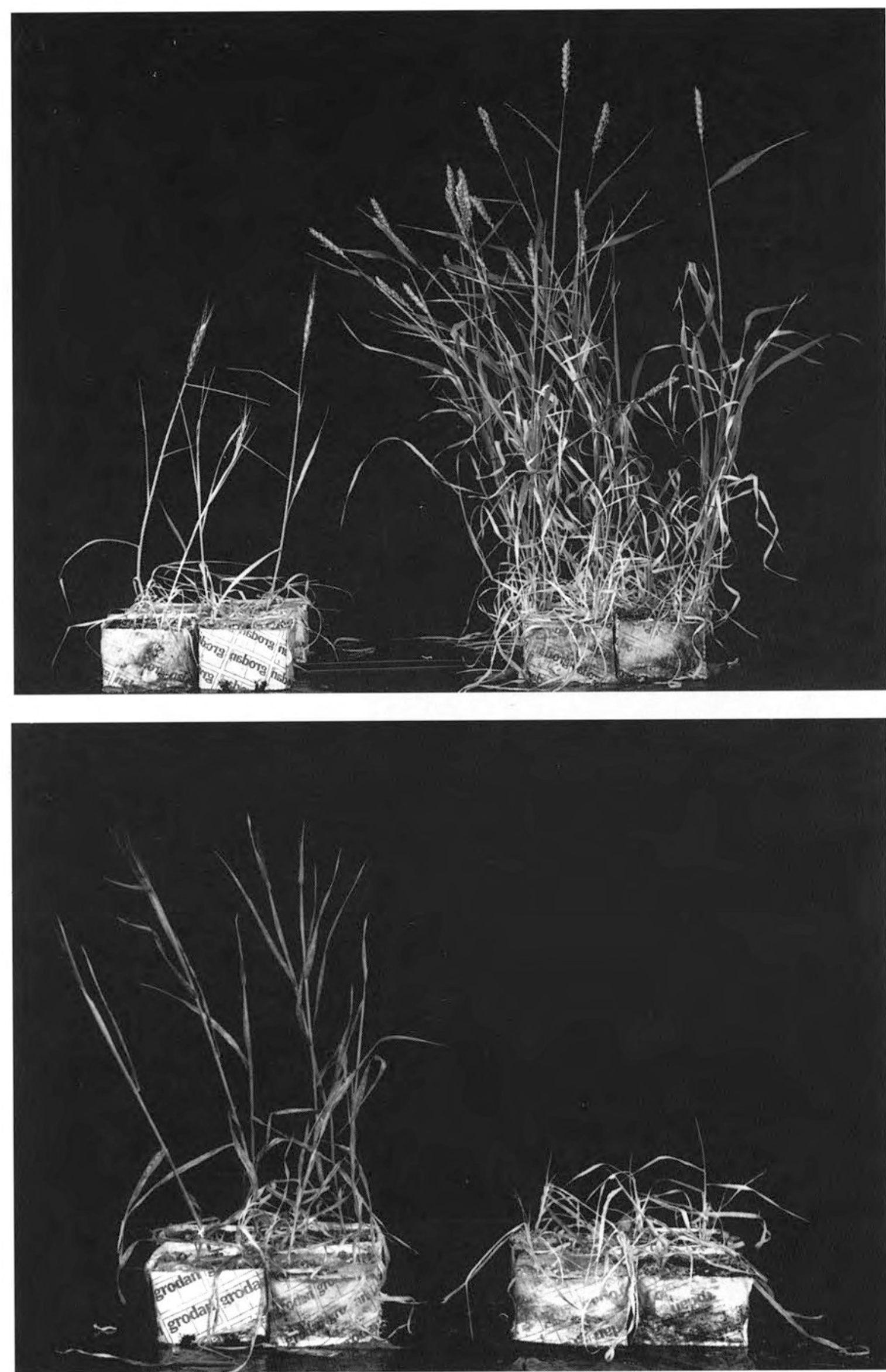

B

Fig 3. Genetic variation for response to $200 \mathrm{mM} \mathrm{NaCl}$ in NFT. A: bread wheat cvs. Glennson (left), CS (right); B: barley cvs. Blenheim (left), Digger (right). 
The relatively poor performance of the $5 \mathrm{E}^{\mathrm{b}}$ line at $200 \mathrm{mM}$ $\mathrm{NaCl}$ was disappointing, since it has been reported to be both more salt tolerant than CS at this salt concentration (Forster et al. 1988), as well as being a more efficient excluder of $\mathrm{Na}^{+}$ from the leaves (Mahmood and Quarrie 1993). Prior experiments, using NFT, have shown that the presence of this alien chromosome is associated with the ability to survive longer at $300 \mathrm{mM} \mathrm{NaCl} / 15 \mathrm{mM} \mathrm{CaCl} 2$ than $\mathrm{CS}$ (unpublished data). However, under $200 \mathrm{mM} \mathrm{NaCl} \mathrm{NFT}$, it under-performed its bread wheat parent in the vegetative parameters measured, although was slightly superior with respect to survival to ear emergence and the ability to set seed. A probable origin of this apparent inconsistency is that chromosome $5 \mathrm{E}^{\mathrm{b}}$ also carries genes which, when present along with the complete wheat genome, are detrimental to plant performance, as, like the majority of alien addition lines, this genotype is less vigorous than its euploid wheat parent when grown necessarily thrive, in high $\mathrm{Na}^{+}$environments.

It is clear that the amphiploid parent of the $5 \mathrm{E}^{\mathrm{b}}$ line is substantially more salt tolerant, and thus that other genes that contribute to this effect are present on one or more of the other six Th. bessarabicum chromosomes. This is underlined by the clear difference in salt tolerance between the backcross derivatives from the amphiploid and the amphiploid itself (Fig. 4). It is well documented that the imposition of salinity $(\mathrm{NaCl})$ stress inhibits protein synthesis (Aspinall 1986), and there is evidence that excess $\mathrm{Cl}^{-}$can be responsible for such interference, (Weber et al. 1977). Although it has been thought that $\mathrm{Na}^{+}$is the primary toxic species, it is thus possible that $\mathrm{Cl}^{-}$excess is responsible for some of the effects observed upon application of salt stress. The role played by $\mathrm{Na}^{+}$may indeed be a passive one, with its effect being largely due to a reduction in cytoplasmic $\mathrm{K}^{+}$concentration, thereby increasing the cytoplasmic $\mathrm{Cl}^{-}: \mathrm{K}^{+}$ratio. Therefore, genotypic differences in a range of physiological processes, which include $\mathrm{Na}^{+}, \mathrm{K}^{+}$and $\mathrm{Cl}^{-}$uptake and partitioning, ability to prevent or reduce the accumulation of highly toxic $\mathrm{NH}_{4}^{+}$ions within the plant tissues as a result of interference in the $\mathrm{N}$-assimilation pathway, and the ability to cope with the osmotic stress that accompanies salinity stress, are all possible sources of salt tolerance.

The selection regime of NFT with $260 \mathrm{mmol} \mathrm{NaCl}$ effectively discriminated between the wheat parent of the amphiploid and the amphiploid itself, and the chromosomal basis of the

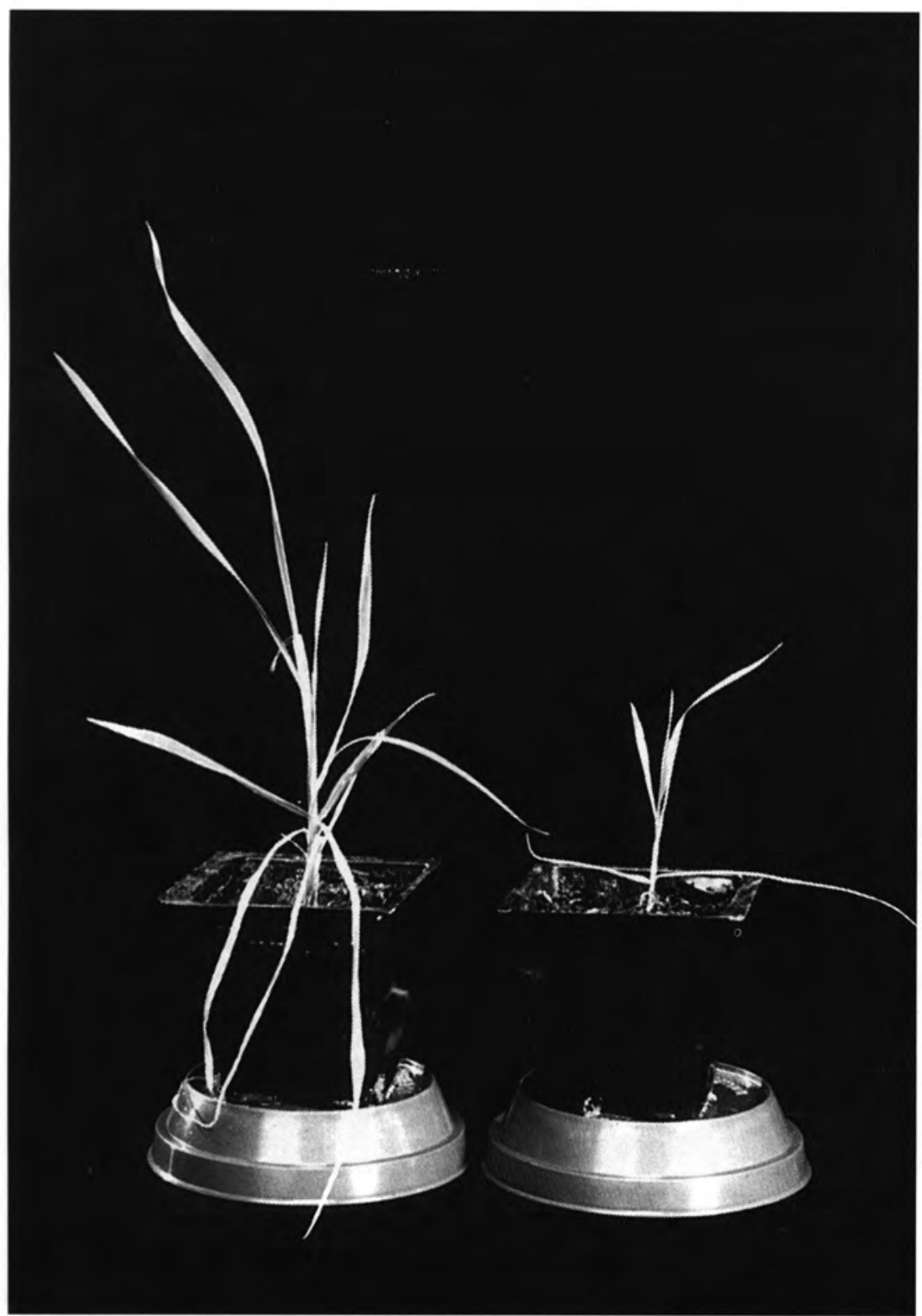

FIG. 4 Wheat $\mathrm{x}$ Th. bessarabicum amphiploid (left) and backcross derivative (right) rescued after 6 weeks at, $260 \mathrm{mM} \mathrm{NaCl}$ and potted into soil. 
surviving backcross derivatives is now being investigated. We suggest that using an appropriate nutrient regime in the NFT hydroponics system imposes a lower level of inherent stress than does the bowl hydroponic system. Thus it is much better suited for the study of the effects of salt stress upon plants, and in particular, may enable the elucidation of a plausible physiological basis for salt tolerance, which would allow for the ready identification and manipulation of salt tolerance genes. The screening system described further provides a selection strategy for tolerance to high levels of salinity stress. Nevertheless, it will be important to combine both this survivability character with an ability to maintain biomass production at moderate levels of stress, as field levels of salinity are rarely uniformly high. A possible screening strategy may thus be to select for survivability at high $\mathrm{NaCl}$ concentrations (e.g., $260 \mathrm{mmol}$ ), and subsequently subject the selections to a lesser level of stress (e.g., $150 \mathrm{mmol}$ ) to evaluate productive agronomic characters.

\section{ACKNOWLEDGEMENTS}

The authors are grateful to Grodan (U.K.) for their advice and the provision of the rockwool blocks used in this study. We would also like to thank D. Laurie, S. Reader (Cambridge Laboratory, JI Centre) and H. Bockelman (US National Small Grains Collection) for the provision of seed stocks.

\section{LITERATURE CITED}

ASPINALL D., 1986. Metabolic effects of water and salinity stress in relation to expansion of the leaf surface. Aust. J. Plant Phys. 13: 59-74.

BLAABJERG J., 1983. Physical and chemical compositions ofthe inactive growing medium Grodan and its felds of application and extension. Acta Hort. 133: 53-57.
BLAABJERG J., 1984. Information on the latest results of growing on Grodan. Acta Hort. 150: 589-592.

CLARK O.L., 1916. A method for maintaining a constant volume of nutrient solutions. Science 44: 868.

FORSTER B.P., MILLER T.E., LAW C.N., 1988. Salt tolerance of two wheat-Agropyrum junceum disomic addition lines. Genome 30: 559564.

GORHAM J., McDONNELL E., BUDREWICZ E., WYN JONES R.G., 1985. Salt tolerance in the Triticeae. Growth and solute accumulation in leaves of Thinopyrum bessarabicum. J. Exp. Bot. 36:1021-1031.

HEWITT E.J., 1966. Sand and water culture methods used in the study of plant nutrition. Farnham, UK: Commonwealth Agriculture Bureaux.

KINGSBURY R.W., EPSTEIN E., 1984. Selection for salt resistant spring wheat. Crop Sci. 24: 310-315.

LAW C.N., 1984. Cooperative experiment to study genotype/environment interaction amongst a set of intervarietal substitution lines having different genes for vernalisation and daylength response. European Wheat Aneuploid Cooperative Newsletter 1984: 3-6.

MAHMOOD A., QUARRIE S.A., 1993. Effects of salinity on growth, ionic relations and physiological traits of wheat, disomic addition lines from Thinopyrum bessarabicum, and two amphiploids. Plant Breed. 110: 265-276.

MARTIN P.K., TAEB M., KOEBNER R.M.D., 1993. The effect of photoperiod insensitivity on the salt tolerance of amphiploids between bread wheat (Triticum aestivum) and sand couch grass (Thinopyrum bessarabicum). Plant Breed. 111: 283-289.

SONNEVELD C., 1989. Rockwool as a substrate in protected cultivation. Chronica Hort. 29: 33-36.

THYS C., VANTHOMME P., SCHREVENS E., DE PROFT M., 1991. Interactions of $\mathrm{Cd}$ with $\mathrm{Zn}, \mathrm{Cu}, \mathrm{Mn}$ and $\mathrm{Fe}$ for lettuce (Lactuca sativa L.) in hydroponic culture. Plant, Cell Envir. 14: 713-717.

WEBER L.A., HICKEY E.D., MARONEY P.A., BAGLIONI C., 1977. Inhibition of protein synthesis by chloride. J. Biol. Chem. 252: 4007-4010.

\title{
ZASTOSOWANIE TECHNIKI POŻYWKI CIENKOWARSTWOWEJ JAKO METODY DO OCENY REAKCJI ROŚLIN NA STRES ZASOLENIA U ZBÓŻ.
}

\begin{abstract}
STRESZCZENIE
Metoda cienkowarstwowej pożywki (NFT) w połączeniu z wełną mineralną została użyta do oceny reakcji pszenicy i jęczmienia na zasolenie. Pszenica rosnąca w układzie NFT/wełna mineralna i w wysokiej koncentracji 200 nmoli $\mathrm{NaCl}$ rozwijała się wegetatywnie lepiej niż w przypadku umieszczenia roślin ponad naczyniami zawierającymi roztwór soli o tej samej koncentracji. Zaobserwowano też, że na stres spowodowany zasoleniem, różne odmiany pszenicy i jęczmienia reagowały niejednakową intensywnością wzrostu. Umieszczając pojedyncze siewki w zminiaturyzowannych tamponach wełny mineralnej, utworzono dogodny system kontroli odporności pszenicy na zasolenie. System ten umożliwia jednoczesne testowanie znacznej liczby roślin. Siewki, które przetrwały 4 tygodnie w warunkach doświadczalnych, przeniesiono następnie do gleby, gdzie rozwijały się dalej normalnie.
\end{abstract}

SŁOWA KLUCZOWE: stres zasolenia, uprawa hydroponiczna, technika pożywki cienkowarstwowej, rośliny zbożowe. 